\title{
Effect of zinc on milkfish nastar-cookies to albumin and hemoglobin levels in HIV/AIDS patients
}

\author{
Nurul Hindaryani ${ }^{1}$, Muchlis Achsan Udji Sofro ${ }^{2}$, Tri Winarni Agustini ${ }^{3 *}$
}

\section{ABSTRACT}

Background: Human Immunodeficiency Virus (HIV) destroys the antibody system, which causes faster protein breakdown resulting in lower albumin concentration. Zinc supplementation when added to protein in milkfish flour may increase albumin and zinc levels that associated with activity of the aminolevulinic acid dehydrase (ALAD) that synthesizes heme.

Objectives: This study aimed to prove the effect of zinc and milkfish flour addition on albumin and hemoglobin levels in HIV/AIDS patients.

Methods: An experimental study with randomized pre and post-test with the control group design using control subjects $(n=17)$ and treatment $(n=21)$. The administration of milkfish nastar with zinc to treatment group was $100 \mathrm{~g} /$ day for 60 days, while the control group was given milkfish nastar without zinc $100 \mathrm{~g} /$ day for 60 days. The measurement of albumin level used auto photometric with enzymatic color test methods and reticulated method for hemoglobin level measurement conducted before and after treatments. Data were analyzed using Shapiro-Wilk, paired t-test, and independent t-test with a significance value at $p<0.05$.

Results: The means of albumin level in the treatment group increased by $7.03 \%$, while the control group increased by $4.33 \%$ $(p>0.05)$. Means of hemoglobin level in the treatment group increased by $12.0 \%$, while the control group increased by $7.9 \%$ $(p<0.05)$.

Conclusion: Albumin and hemoglobin levels increased after milkfish nastar administration with zinc addition in HIV/AIDS patients.

Keywords: albumin; HIV-AIDS; hemoglobin; milkfish nastar cookies; zinc supplementation

\section{INTRODUCTION}

Human Immunodeficiency Virus (HIV) is a worldwide threatening disease caused by dangerous pathogens, namely retroviridae. The numbers of people with HIV each year increase and grow rapidly in all parts of the world. HIV can develop into Acquired Immune Deficiency Syndrome (AIDS), one of the most prevalent diseases and needs to be given serious attention in the "Global Burden Disease". The cumulative numbers of AIDS in Indonesia in June 2016 were reported to be 208,920 people infected with HIV and 82,556 people with AIDS. East Java Province is the second of 10 provinces in Indonesia that affected with HIV cases of 27,575, while for AIDS cases of 16,431. The fact of HIV/AIDS until the end of June 2016 was recorded 1,741 cases, in Sidoarjo regency including the fifth highest in productive age more than $80 \% .{ }^{1}$ Krian sub-district was ranked third with a total of 162 cases of HIV/AIDS in 2011 to June 2016. ${ }^{1,2}$

Albumin levels in patients with HIV/AIDS decreased, followed by a decrease in blood hemoglobin levels. The consumption of food sources of albumin and hemoglobin can increase levels of albumin and hemoglobin in the blood. Besides that, the addition of zinc supplements increase albumin levels and stimulates thymulin hormone that requires zinc as cofactor to perform a biological activity. Several studies state that zinc levels affect the amount of Claustar of Differentiation (CD4) and zinc supplementation can improve immunity, CD4 is a $\mathrm{T}$ cell marker helper that plays an important role in immune, especially cellmediated immunity. The low levels of hemoglobin in HIV/AIDS patients increase the prevalence of anemia to be quite high, ranging from $1.3 \%$ to $95 \%$, depending on the stage of the disease. The higher stage of the patient, the higher incidence of anemia and increased morbidity and mortality. Treatment of anemia is necessary to improve and maintain the hemoglobin level in the blood to remain normal. ${ }^{3,4}$

Milkfish is known as one of the food sources that contain high albumin. The content of albumin and amino acids in milkfish is an alternative protein source to overcome hypoalbuminemia in people with HIV/AIDS. The shelf life of Milkfish can be improved by changing this to fish flour, which can be used as the basic ingredients of nastar cookies which is preferred by everyone. ${ }^{5}$ Nastar is a kind of pastry made from wheat flour, refined sugar, margarine, yolks and filled with pineapple jam, usually used as a dish during holidays

\footnotetext{
${ }^{1}$ Departement of Nutrition Science, Faculty of Medicine, Universitas Diponegoro. Prof Soedarto, SH. Street, Tembalang, Semarang 50275, Indonesia.

${ }^{2}$ Departement of Fishery Products Technology, Faculty of Fisheries and Marine Science, Universitas Diponegoro. Prof Soedarto, SH. Street, Tembalang, Semarang 50275, Indonesia.

${ }^{3}$ Internal Medicine of RSUP. Dr. Karyadi Semarang, Faculty of Medicine, Universitas Diponegoro. Prof Soedarto, SH. Street, Tembalang, Semarang 50275, Indonesia.

*Corresponding authors: E-mail : tri.agustini@live.undip.ac.id
} 
such as Eid Al Fitr and Christmas because of the ideal flavor between sweet and savory, crunchy texture and has a long shelf life. The addition of zinc supplements on milkfish nastar cookies aims to increase levels of albumin and hemoglobin in HIV/AIDS patients. ${ }^{5,6}$ Based on this problems, this study aimed to explore the effect of zinc and milkfish flour addition on albumin and hemoglobin levels in HIV/AIDS patients.

\section{MATERIAL AND METHODS}

The study design was a true experimental study with a randomized pre-post test design with a control group design. The second stage, people of HIV/AIDS that was registered at the Primary Health Care Krian, Sidoarjo from February to April 2018 was divided into the control and intervention groups. The number of subjects was 38 people that was consisted of 21 people in intervention group were given $100 \mathrm{~g} /$ day of milkfish nastar cookies additioned with $13 \mathrm{mg} / \mathrm{day}$ of zinc supplementation, 17 people as control were given 100 g/day of milkfish nastar cookies only for 60 days, respectively. Albumin levels were measured by using $1.5 \mathrm{ml}$ of blood samples and were placed in the vacutainer with EDTA anticoagulants with BCG enzymatic color test method plus cobas brand. Hemoglobin levels were measured by using $1.5 \mathrm{ml}$ of blood samples with a new methylene blue method.

In the making of nastar cookies, the basic recipe was used to make milkfish nastar with the ingredients like fresh milkfish were obtained from the nearest traditional market to be used as flour, and added with other ingredients like wheat flour $(400 \mathrm{~g})$, milkfish flour (50 g / 12.5\%), margarine (200 g), refined sugar (100 $\mathrm{g})$, yolk (160 g), and filled with pineapple jam (40 g). The tools used to make milkfish nastar cookies were mixer, cake scales, plastic basins, spatulas, stoves, baking pan, and oven. Nastar in the making by mixing sugar and margarine, shake until smooth, and then add yolks, fish flour, and wheat flour. Mix them until homogeneous and take $100 \mathrm{~g}$ of dough, then divided them into ten pieces in a baking pan, apply with yolks, and put into oven till cooked. Nastars were packed into plastic that consisted of 10 pieces of cookies $(100 \mathrm{~g})$ in serving.

\section{RESULTS}

The numbers of the subject in this study were 41 people. Two people were dropped out because of noncompliance, so that at the end of the study, the numbers of the subject were 38 people. The subjects of the study were 38 people that consisted of 21 people in intervention group that were given $100 \mathrm{~g}$ /day of milkfish nastar cookies additioned with $13 \mathrm{mg}$ /day of zinc supplementation and 17 people in control group were given milkfish nastar cookies without zinc additional. The characteristic of subject by sex and nutritional status based on BMI were shown in Table 1 .

Table 1. Characteristic Subjects by Sex and Nutritional Status

\begin{tabular}{lcccc}
\hline \multicolumn{1}{c}{ Characteristics } & \multicolumn{2}{c}{ Intervention group $(\mathbf{n}=\mathbf{2 1})$} & \multicolumn{2}{c}{ Control group $(\mathbf{n}=\mathbf{1 7})$} \\
\cline { 2 - 5 } & $\mathbf{n}$ & $\mathbf{\%}$ & $\mathbf{n}$ & \% \\
\hline Sex & 7 & 33.3 & 9 & 52.9 \\
Male & 14 & 66.7 & 8 & 47.1 \\
Female & & & & \\
Nutritional status before intervention* & 3 & 14.3 & 4 & 23.5 \\
$\quad$ Underweight $\left(<18.5 \mathrm{~kg} / \mathrm{m}^{2}\right)$ & 9 & 42.9 & 4 & 23.5 \\
$\quad$ Normal $\left(18.5-22.9 \mathrm{~kg} / \mathrm{m}^{2}\right)$ & 4 & 19.0 & 4 & 23.5 \\
Overweight $\left(23.0-24.9 \mathrm{~kg} / \mathrm{m}^{2}\right)$ & 5 & 23.8 & 5 & 29.4 \\
Obesity $\left(\geq 25 \mathrm{~kg} / \mathrm{m}^{2}\right)$ & & & & \\
Nutritional status after intervention* & 2 & 9.5 & 3 & 17.6 \\
Underweight $\left(<18.5 \mathrm{~kg} / \mathrm{m}^{2}\right)$ & 11 & 52.4 & 5 & 29.4 \\
Normal $\left(18.5-22.9 \mathrm{~kg} / \mathrm{m}^{2}\right)$ & 3 & 14.3 & 3 & 17.6 \\
Overweight $\left(23.0-24.9 \mathrm{~kg} / \mathrm{m}^{2}\right)$ & 5 & 23.8 & 6 & 35.3 \\
Obesity $\left(\geq 25 \mathrm{~kg} / \mathrm{m}^{2}\right)$ & &
\end{tabular}

Table 1 showed that the sex of HIV/AIDS subjects in the intervention group was 14 people $(66.7 \%)$ of male and 7 people $(33.3 \%)$ of female, while the control group was 9 people $(52.9 \%)$ of male and 8 people $(47.1 \%)$ of female. The highest number of subjects was shown in female by 22 people. The category of nutritional status in patients with HIV/AIDS based on body mass index in intervention group, underweight subjects decreased from 3 people $(42.9 \%)$ to 2 people (9.5\%), normal subjects increased from 9 people $(42.9 \%)$ to 11 people $(52.4 \%)$, overweight subjects decreased from 4 people $(19.0 \%)$ to 3 people (14.3\%) and 5 people of obesity status (23.8\%). In control group, underweight subjects decreased from 4 people $(23.5 \%)$ to 3 people (17.6\%), normal subjects increased from 4 people (23.5\%) to 5 people $(29.4 \%)$, overweight subjects decreased from 4 people $(23.5 \%)$ to 3 people $(17.6 \%)$ and obesity subjects increased from 5 
people (29.4\%) to 6 people $(35.3 \%)$. The highest increased was shown in normal nutritional status in intervention group.

\section{Effect of Zinc Addition on Milkfish Nastar Cookies} to Albumin Levels

The mean of albumin levels before and after treatment of milkfish nastar cookies in intervention and control groups were shown in Table 2.

The mean of albumin levels in the control and intervention groups after treated with milkfish nastar showed a significant increase $(\mathrm{p}<0.05)$ (Table 2$)$. The greatest increase in the mean value of albumin levels was the intervention group $(7.03 \%)$. Based on independent $t$-test, the mean of albumin levels between groups showed a significant difference $(\mathrm{p}<0.05)$.

Effect of Zinc Addition on Nastar Fish Cake Milkfish to Hemoglobin Levels

The mean of hemoglobin levels before and after treatment of milkfish nastar cookies in intervention group and control group were shown in Table 3.

Table 2. Mean of Albumin Levels Before and After Treatment

\begin{tabular}{lccc}
\hline & \multicolumn{2}{c}{ Groups } & \multirow{2}{*}{$\boldsymbol{p}^{\boldsymbol{I}}$} \\
\cline { 2 - 3 } & Control $(\mathbf{n = 1 7})$ & Intervention $(\mathbf{n = 2 1})$ & \\
\hline Before treatment & $4.24 \pm 0.335$ & $4.14 \pm 0.276$ & \multirow{2}{*}{0.072} \\
After treatment & $4.40 \pm 0.201$ & $4.46 \pm 0.257$ & \\
$\Delta$ pre-post & $0.16 \pm 0.257$ & $0.31 \pm 0.254$ & \\
$p$ & 0.018 & 0.000 & \\
$\%$ changes & $4.33 \pm 7.13$ & $7.03 \pm 7.19$ & \\
\hline$p=$ dependent $t$-test; $p^{I}=$ independent $t$-test & & &
\end{tabular}

Table 3. Mean of Hemoglobin Levels Before and After Intervention 60 Days

\begin{tabular}{|c|c|c|c|}
\hline & \multicolumn{2}{|c|}{ Groups } & \multirow{2}{*}{$p^{l}$} \\
\hline & Control $(n=17)$ & Intervention $(\mathrm{n}=\mathbf{2 1})$ & \\
\hline Before treatment & $0.88 \pm 0.283$ & $0.89 \pm 0.361$ & \\
\hline After treatment & $0.89 \pm 0.207$ & $0.90 \pm 0.279$ & 0.000 \\
\hline$\Delta$ pre-post & $0.005 \pm 0.336$ & $0.009 \pm 0.33$ & \\
\hline$\%$ changes & $7.9 \pm 30.7$ & $12.0 \pm 46.57$ & \\
\hline$P$ & 0.943 & 0.898 & \\
\hline
\end{tabular}

The mean of hemoglobin levels in the control and intervention groups after treated with milkfish nastar did not show significantly different $(\mathrm{p}>0.05)$ (Table 3 ). The greatest increase in the mean value of hemoglobin levels was found in intervention group (12.00\%). Based on independent t-test, the mean of hemoglobin levels between groups showed a significant difference $(\mathrm{p}<0.05)$.

\section{DISCUSSION}

Increased levels of albumin in both groups, control and intervention group were due to subject received the same treatment of FDC (Fixed dose combination) type and being in a second stage of HIV/AIDS infections in line with Lubis's study if no more opportunistic infections increased in albumin levels. Physiologically, healthy adults have a stable protein in the body, with the need for $90 \mathrm{~g}$ of protein a day through a hydrolysis process that is absorbed as a free amino acid. Amino acids come and go from organs and visceral so that from a total of $340 \mathrm{~g}$ of amino acids that enter the pool or stored only $25 \%$ of daily food intake. Free amino acids scattered in the body are cells, blood, and extra fluid cells. Intake of protein through the process of secretion and absorbed in the liver, into plasma protein $(20 \%)$ divided into $12 \mathrm{~g}$ of albumin, white blood cells $(20 \mathrm{~g})$, red blood cells $(8 \mathrm{~g})$, and others $8 \mathrm{~g}$. While the largest composition of protein synthesis results in visceral, brain, and lung by $50 \%$. 3,4

The source of animal protein needed by HIV/AIDS patients to accelerate the increase in albumin levels is found in all essential amino acids, such as eggs, meat, chicken, and fish. Based on the results of laboratory tests of the highest animal albumin content derived from gabus fish, milkfish, and shellfish. Low protein in vegetable sources will contain essential amino acids, such as beans, tempeh, tofu, and oncom. Rice is also a vegetable protein that contributes considerable protein intake to Indonesians. Protein is a macronutrient that needed for growth; energy sources, especially proteins, can be an enzyme-forming component, blood carrier, creatine producer, collagen, muscle, bone, skin, hair, and hormones. The essential amino acids that important for daily are isoleucine, leucine, lysine, methionine, valicidine, and histidine., ${ }^{4,7}$

Zinc as a transport in plasma is transported by albumin by $57 \%, 40 \%$, $\alpha$-macroglobulin, and $3 \%$ by molecules with low ligand weight such as amino acids. Albumin carries zinc to the liver after it is reshaped and circulated into $\alpha 2$-macroglobulin circulation. Zinc will be compounded with phosphate $\left(\mathrm{PO}_{2}\right)$, chloride $(\mathrm{Cl})$, 
and carbonates ( $\mathrm{HCO})$ such as histidine and cysteine. The small molecule that helps the absorption of zinc is metallothioneine, which is responsible for regulating intracellular zinc concentrations for unimportant heavy metal detoxification. High intake of zinc in the gastrointestinal tract will be converted to metallothionine and will bind zinc in the liver, kidneys, and intestines are removed when needed. Zinc is required for both cellular defense and humoral immune response, as cofactors of 200 enzymes (RNA polymerase, alcohol dehydrogenase, synthesis DNA) and metabolism of various hormones like insulin hormone, thyroid hormone and growth hormone. ${ }^{8,9}$ There is not much evidence study about the amount of protein intake with chronic diseases, especially in HIV/AIDS patients in Asian countries, as well as studies on zinc deficiency in the system. Still, there is evidence study that choosing healthy sources of protein (fish, chicken, and beans) compared with red meat consumption and its preparations can reduce the risk of some non-communicable diseases and the risk of premature death. ${ }^{7,10}$

Hemoglobin levels showed the greatest increase in the treatment group of $12 \%$ increase because the intervention group got treatment with the addition of zinc supplements with a dose of $13 \mathrm{mg} /$ day mixed on milkfish nastar cake for 60 days. This study is also supported by previous research that the content of hemoglobin and zinc in a variety of food is usually contained in a relatively small amount, so the analysis required methods that have good sensitivity and selectivity. Two-thirds of the body's iron is found in hemoglobin and circulates in the enterocyte circulation. Another is in muscle mass myoglobin and some of the enzymes necessary for metabolic processes and other functions. The exchange of iron in each person's body is not the same because its iron absorption and the mutual adhesions are adjusted in a normal subject representing $1 \mathrm{mg} /$ day in each direction. The iron metabolism occurs because the body needs iron for protein synthesis, which carries oxygen, namely hemoglobin and myoglobulin and synthesizes ironcontaining enzymes to participate in electron displacement reactions in the oxidation reaction of reduction. The active proteins in the duodenum are carried through the mucous membrane into the blood then the carrier proteins (transferrin) present in the cells transport into cells and bone marrow. There are three stages of the process of the formation of iron deficiency conditions with different degrees of severity and range from mild to severe. The first stage, reduced iron deposits in marked with low serum ferritin levels, then the second stage marked with biochemical changes that reflect the lack of iron in the production of normal hemoglobin. The third stage occurs iron deficiency called anemia. ${ }^{4,7,11,12}$
Albumin is a blood protein that acts as the main transport of zinc in improving the body's immune system. Zinc can help the body's biological processes and function in the formation of hemoglobin. Hemoglobin is formed by succinyl CoA derived from the acid cycling cycle in mitochondria and amino acid glycine. The result of the condensation reaction between succinyl CoA and glycine is $\alpha$-amino$\beta$ ketoadipic acid, which rapidly decarboxylated to form $\alpha$-aminolevulinate (ALA). ALA formation occurs in mitochondria, cytosol and two ALA molecules condensed by ALA dehydratase enzyme for two water molecules and one porphobilinogen (PBG). ALA dehydratase is an enzyme-containing zinc as a key enzyme in heme biosynthesis; zinc deficiency will affect the formation of heme. . $^{43,14}$

Iron deficiency in people with HIV/AIDS can affect the low levels of hemoglobin in the body that can affect several factors, such as a person's work performance or work capacity. This indicates that tissue which has iron deficiency causes interference with organ function as in a skeletal muscle. Other nutritional deficiencies play a role in the formation of hemoglobin, either due to a lack of consumption or absorption disorders. These nutrients come from an animal, zinc, folic acid, pyridoxine (vitamin B6), vitamin A, vitamin $\mathrm{C}$, and some other micromineral. Disease status, some types of diseases can affect hemoglobin levels, chronic diarrheal diseases, opportunistic infections in people with HIV/AIDS and parasitic infections such as Plasmadium falciparum in Malaria resulting in low hemoglobin with erythrocyte rupture. , $^{75,16}$

High intake of manganese inhibits the absorption of iron because manganese and iron form the same absorption path resulting in competition. Polyphenols, including tannins, are present in coffee, tea, chocolate, and some vegetables that form an insoluble complex in iron that can reduce the uptake of iron by up to $70 \%$. Current research suggests that iron deficiency anemia is not only caused by iron deficiency alone but also deficiencies of other substances such as folic acid, zinc, vitamin A and others. There were several other factors that can affect a person's hemoglobin level, individual biological variations, measurement of evening hemoglobin levels lower than mornings, sex, age causing different hemoglobin levels, presence individuals at certain altitudes cause a self-adjusting response to decrease oxygenated blood pressure and reduce oxygen saturation in the blood. When at an altitude of 1000 meters, hemoglobin will increase. ${ }^{8,17,18}$

Some factors that can affect anemia, such as in adults, can absorb iron in the diet is only about 5-15\% with good iron status. While in the state of iron absorption deficiency reaches $50 \%$ due to many factors to iron absorption among others, factors that can increase iron absorption, increase food acidity or gastric 
will facilitate the absorption of iron with the $\mathrm{Fe}^{2+}$. In adults, the addition of vitamin $\mathrm{C}$ in the diet increases iron uptake by as much as $85 \%$. Animal protein obtained from beef, chicken, fish increases iron absorption $20-40 \% .4,19,20$

\section{CONCLUSIONS}

Administration of zinc supplements with a dosage of $13 \mathrm{mg} /$ day and milkfish flour on $100 \mathrm{~g} /$ day nastar cookies for 60 days can increase albumin and hemoglobin levels in people with HIV/AIDS. Zinc supplementation and milkfish nastar cookies can be used as an alternative to overcome the decrease of albumin and hemoglobin levels. Further study is needed to zinc supplementation and milkfish nastar cookies in HIV/AIDS patients with other study variables.

\section{REFERENCES}

1. Back-Brito GN, El Ackhar VNR, Querido SMR, dos Santos SSF, Jorge AOC, Reis ASM et al. Sthapylococcus spp, enterobacteriaceae and pseudomonadaceae oral isolates from brazilian HIVpositive patients. correlation with CD4 cell counts and viral load. Arch Oral Biol. 2011;56(10):1041-6.

2. Yuliyanasari N. Global burden desease human immunodeficiency virus acquired immune deficiency syndrome (HIV/AIDS). Qanun Medika. 2017;1(1):65-77.

3. Alvarez-Uria G, Midde M, Pakam R, Naik PK. Diagnostic and prognostic value of serum albumin for tuberculosis in HIV infected patients eligible for antiretroviral therapy: data from an HIV cohort study in India. Bioimpacts. 2013;3(3):123-8.

4. Suharto S, Saptaningrum E, Wijayanti K, Sutarmi S, Warijan W, Hendromastuti A et al. The influence of zinc supplementationon nutritional status among children under five years of age at Blora district. Jurnal Keperawatan Indonesia. 2011;1(1):1-9.

5. Mocchegiani E, Muzzioli M. Therapeutic application of zinc in human immunodeficiency virus againsts opportunistik. J Nutr. 2000;130:142431.

6. Asikin A, Bambang W, Soeroso J. Zinc sulfate increases lymphocyte CD4 count in HIV/AIDS patients at icuid Dr. Soetomo Hospital Surabaya. FMI. 2012;48:17-19.

7. Rahfiludin MZ, Ginandjar P. The effect of zinc and vitamin $\mathrm{c}$ supplementition on hemoglobin an hematocrit levels and immune respons impatients with plasmadium vivax malaria. Southeast Asian J Trop Med Public Health. 2013;44(5):733-9

8. Boldt J. Use of albumin : an update. Br J Anaesth. 2010;104(3):276-84)
9. Glabska D, Staniec A, Guzek D. Assessment of validity and reproducibility of the zinc-specific dietary intake questionnaire conducted for young polish female respondents. Nutrients. 2018;10(1):104.

10.Rahler JF, Ben-Horin S, Chowers Y, Conlon C, De Munter P, D'Haens G et al. Europen evidance based consensus on the prevention, diagnosis and management opportunitic infections in inflammatory bowel disease. J Chron's Colitis. 2009;3(2):47-91.

11.Pasricha SR, Drakesmith H, Black J, Hipgrave D, Biggs BA. Control of iron deviciency anemia in low and middle income countries. Blood. 2013;121(14):2607-17.

12.Nasronudin. HIV \& AIDS Pendekatan Biologi Molekuler, Klinis, dan Sosial. Surabaya: Airlangga University Press;2014.

13.Wu X, Ge J, Yang C, Hou M, Liu Z. Facile synthesis of multiple enzyme-containing metalorganic frameworks in a biomolecule-friendly environment. ChemComm. 2015;51(69):13408-11.

14.World Health Organization. Pencegahan AIDS melalui promosi kesehatan: Masalah yang sensitif. Bandung: Penerbit ITB; 2007.

15.Johannessen A, Naman E, Gundersen SG, Bruun JN. Antiretroviral treatment reverses $\mathrm{HIV}$-associated anemia in rural Tanzania. BMC Infect Dis. 2011;11(1):190.

16.Garg N, White CE. Mechanism of zinc oxide retardation in alkali-activated materials: an in situ Xray pair distribution function investigation. J Mater Chem A. 2017;5(23):11794-804.

17. Anene A, Mba OI, Afam-Anene OC, Nwanguma E. Proximate and mineral quality changes in fillets of three fish species (Mugil cephalus, Chrysichthys nigrodititatus and Oreochromis niloticus) at frozen storage $\left(\mathrm{Sub} 0^{\circ} \mathrm{C}\right)$. International Journal of Nutrition and Food Sciences. 2015;4(3):402-8.

18.Fosu MO, Frimpong FO, Arthur MO. Factors associated with haemoglobin prevalence among Ghanaian children aged 6-59 months. J Biology Agric Healthc. 2014;4(2):132-40.

19. Moretti D, Goede JS, Zeder C, Jiskra M, Chatzinakou V, Tjalsma H, Melse-Boonstra A, Brittenham G, Swinkels DW, Zimmermann MB. Oral iron supplements increase hepcidin and decrease iron absorption from daily or twice-daily doses in iron-depleted young women. Blood. 2015;126(17):1981-9.

20.Gulen H, Hanimeli O, Karaca O, Taneli F. $\alpha$ Thalassemia frequency and mutations in children with hypochromic microcytic anemias and relation with $\beta$-thalassemia, iron deficiency anemia. Pediatr Hematol Oncol. 2012;29(3):241-6. 